\title{
Clinical and Intraoperative Features of Dirofilariasis of the Temporal Region: Case Report*
}

\author{
Vasyl A. Rybak1,", Olga S. Cherniak2,", Pavlo P. Snisarevskyi ${ }^{3}$, and Valentyna I. Zaritska ${ }^{4}$ \\ ${ }^{1}$ Head, Center of Maxillofacial Surgery, Kyiv Regional Clinical Hospital, Kyiv, Ukraine (place of work at moment of article preparing). \\ Head Physician, Municipal Non-Commercial Enterprise "Irpin Stomatology", Irpin, Kyiv Region, Ukraine (place of work at moment of article \\ publication) \\ ${ }^{2}$ Head, Department of Ultrasound, Kyiv Regional Clinical Hospital, Kyiv, Ukraine \\ ${ }^{3} \mathrm{Head}$, Department of Pathomorphology, Kyiv Regional Clinical Hospital, Kyiv, Ukraine \\ ${ }^{4}$ Associate Professor, Department of Pathology, Shupyk National Medical Academy of Postgraduate Education, Kyiv, Ukraine $(P h D)$
}

\section{ABOUT ARTICLE}

Article history:

Paper received 10 June 2018

Accepted 20 August 2018

Available online 25 December 2018

Keywords:

Dirofilariasis

Dirofilaria repens

Threadlike worm

Encapsulation

\begin{abstract}
S U M M A R Y
Dirofilaria (synonym: threadlike worm) is a parasite of domestic and wild animals that can infect humans secondarily by mosquitoes [1]. Our case is strictly demonstrating the features of the Dirofilaria repens located in the temporal area. And we precisely described that stage of absence of Dirofilaria migration as stage of anabiosis (state of greatly reduced metabolism) before its encapsulation stage [2].
\end{abstract}

(c) 2018 OMF Publishing, LLC. All rights reserved.

\section{Introduction}

Dirofilaria (synonym: threadlike worm) is a parasite of domestic and wild animals that can infect humans secondarily by mosquitoes [1]. From the Latin dirus ("fearful", "vicious" or "ominous") + fillum ("thread") [2] and repens ("creeping"). Dirofilariasis is the disease caused by filarial nematodes of the genus Dirofilaria [3]. There are about 40 recognized species of Dirofilaria [4] and the commonest (Joseph et al, 2011) of the Dirofilaria species which infects humans are Dirofilaria repens and Dirofilaria immitis [2]. The lung lesions are caused by Dirofilaria immitis while the subcutaneous lesion is caused mostly by Dirofilaria repens [5]. The purpose of our case report is to highlight the clinical, intraoperative, and postoperative features of Dirofilariasis of the temporal region.

\section{Case Report}

A 31-year-old patient referred to the Maxillofacial Surgery

\footnotetext{
* This manuscript has not been presented

* Corresponding author. MNCE "Irpin Stomatology", 38 Sadova Street, Irpin 08200, Kyiv Region, Ukraine.

Phone: +380630373737

E-mail: rybak.jaws@gmail.com (Vasyl A.Rybak)

E-mails of the co-authors:

cherniak.os@gmail.com (Olga S. Cherniak)

sneip78@gmail.com (Pavlo P. Snisarevskyi)

viomelvi@gmail.com (Valentyna I. Zaritska)

http://dx.doi.org/10.23999/j.dtomp.2018.4.5
}

Center with complaints for a painless nodular swelling in the left temporal region (Figs 1,2) during last month. The patient did not notice any movement (active migration) in the area of swelling. Also, patient did not complain for a spontaneous increasing of swelling in the face similar to allergic reaction. According to patient medical record he lived near the water supply and sewage enterprise in Ukrainka, Kyiv Region. Ultrasound showed an oval shape hypoechoic lesion in cellular tissue in the inferior aspect of the left temporal area. Color and Power Doppler showed no vascularity inside the lesion and in the surrounding tissue. A surgery (enucleation) was done under the general anesthesia. A worms' behavior during (Fig 3) and after the surgery (Fig 4) was the same as in report of Jayasinghe et al (2015) [6]: first a threadlike worm was found to be wriggling for several seconds before it became lifeless. A histopathological evaluation confirms the preoperative diagnsosis. The postoperative period was smooth.

\section{Discussion}

Pampiglione et al (2001) reported about 60 new cases of Dirofilaria repens in Italy during 9 consecutive years [7]. According to their significant amount of cases the Dirofilaria was located in the subcutaneous tissue (49 cases), the epididymis ( 2 cases), the spermatic cord (2 cases), the lung ( 2 cases), the breast ( 2 cases), the omentum (2 cases), and under the conjunctival tissue ( 1 case) [7]. In 2015 Manuel et 
DIROFILARIASIS OF THE TEMPORAL REGION

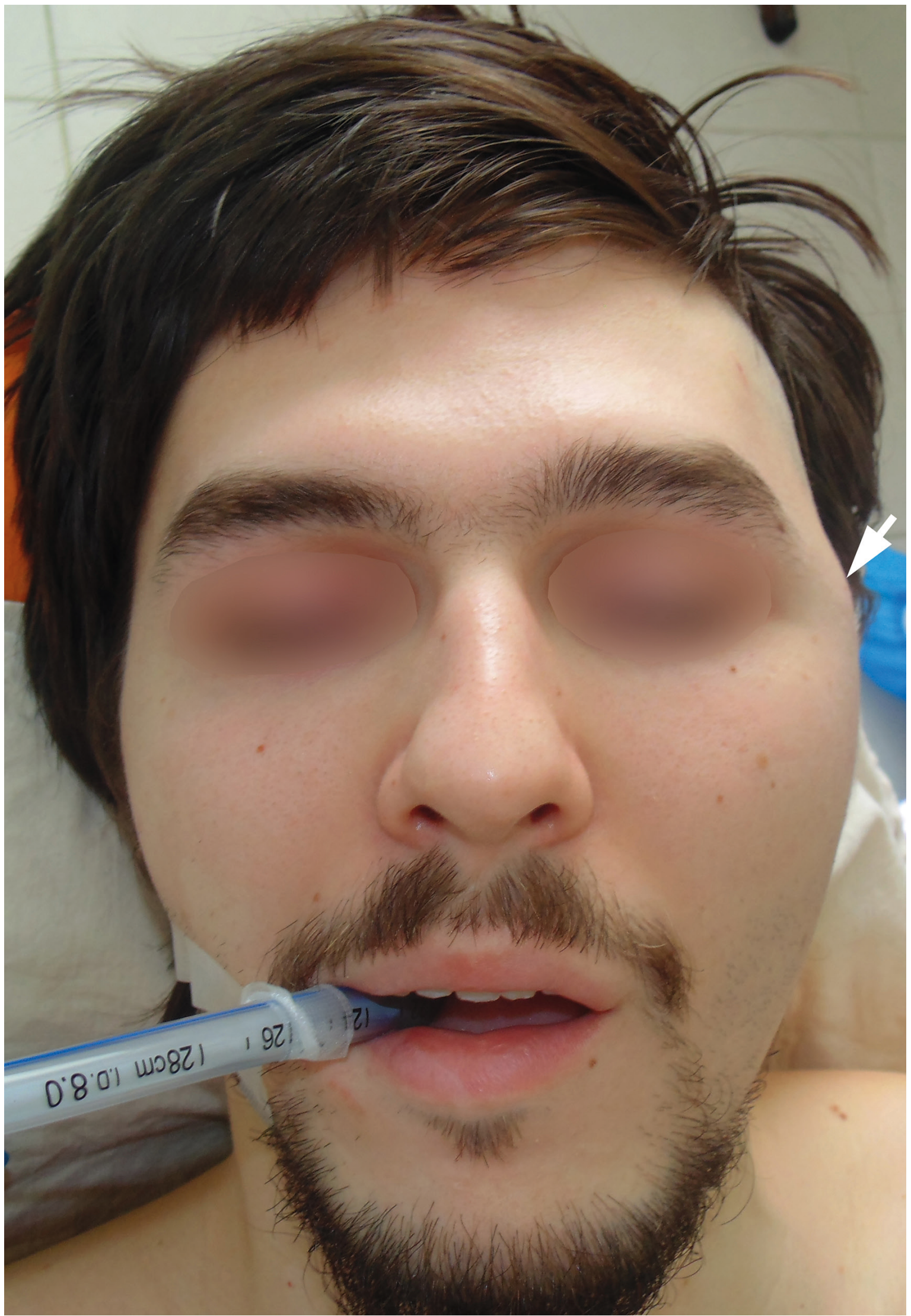

FIGURE 1. Preoperative anterior view: Place of the Dirofilaria repens localization (arrow) at left temporal region before removal. 


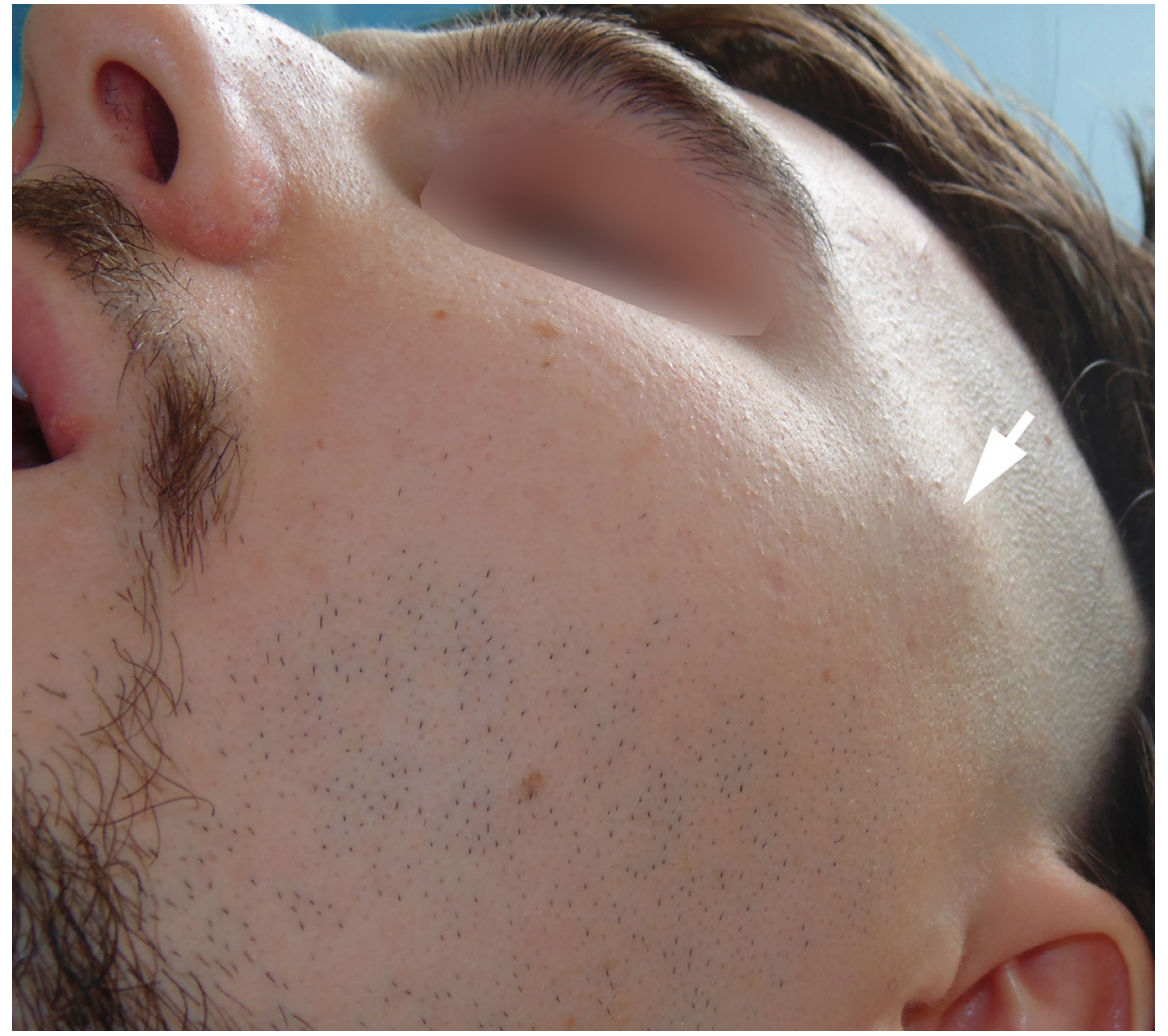

FIGURE 2. Preoperative lateral view: Place of the Dirofilaria repens localization (arrow) at left temporal region before removal.

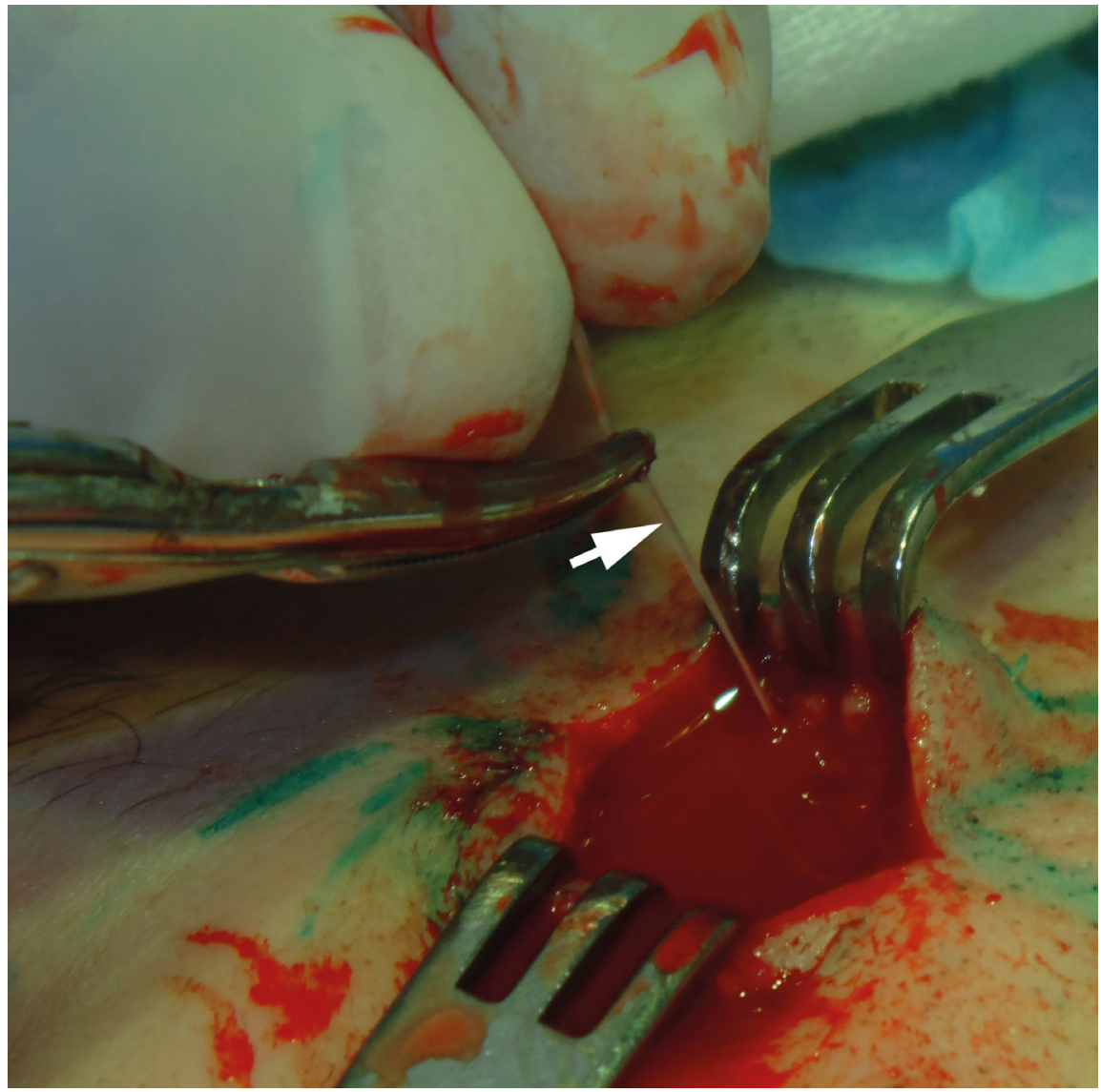

FIGURE 3. Zoomed intraoperative view: Dirofilaria repens (arrow) upon removal. 


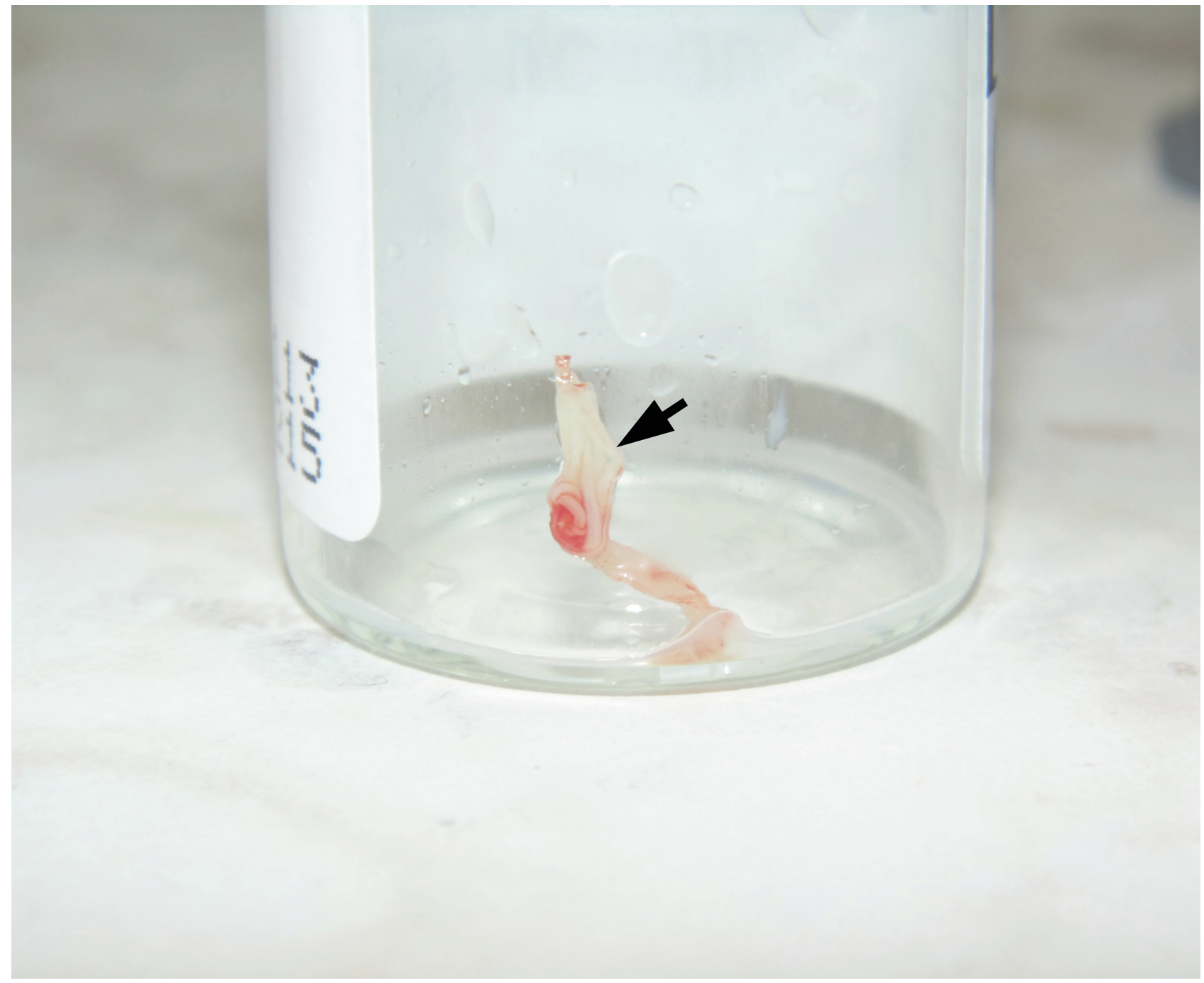

FIGURE 4. Specimen of Dirofilaria repens (arrow) after removal.

al reported only a 13th intraoral case of Dirofilaria published in literature [1]. Also a lot of case reports described ocular Dirofilariasis [8]. Generally, review of literature revealed around 800 Dirofilaria cases distributed worldwide [5]. The prospective study (Ermakova et al, 2017) of 266 patients revealed that proportion of patients with encapsulated parasites was $56.4 \%$; active migration of the parasite was observed in $43.6 \%$ of patients [9].

\section{Conclusions}

Our case is precisely demonstrating the features of the Dirofilaria repens in the stage of absence of migration i.e. stage of anabiosis (Tymofieiev, 2012) (anabiosis is a state of greatly reduced metabolism) before its encapsulation stage [2].

\section{Role of the Co-authors}

Vasyl A. Rybak (concept of the article, writing, and editing). Olga S. Cherniak (material collection).
Pavlo P. Snisarevskyi (material collection).

Valentyna I. Zaritska (material collection).

All authors read and approved the final manuscript.

\section{Term of Consent}

Written patient consent was obtained for publishing the clinical photographs.

\section{Fundings}

No funding was received for this study.

\section{Acknowledgments}

None.

\section{References}

1. Manuel S, Surej Kumar LK, Khalam SA. Oral dirofilariasis: report of a case arising in the buccal vestibular region. $J$ 
Oral Maxillofac Surg, Medicine, Pathol 2015;27(3):418-21. https://doi.org/10.1016/j.ajoms.2014.05.006.

2. Tymofieiev OO. Manual of maxillofacial and oral surgery [Russian]. 5th ed. Kyiv: Chervona Ruta-Turs; 2012.

3. Reddy MV. Human dirofilariasis: an emerging zoonosis. Trop Parasitol 2013;3(1):2-3.

4. Magill AJ, Ryan ET, Solomon T, Hill DR. Hunter's tropical medicine and emerging infectious disease. 9th ed. Saunders; 2013.

5. Joseph E, Matthai A, Abraham LK, Thomas S. Subcutaneous human dirofilariasis. J Parasit Dis 2011;35(2):140-3. https:// doi.org/10.1007/s12639-011-0039-2.

6. Jayasinghe RD, Gunawardane SR, Sitheeque MAM, Wickramasinghe S. A case report on oral subcutaneous
Dirofilariasis. Case Reports in Infectious Diseases 2015; Vol. 2015(648278):4 pages. https://doi.org/10.1155/2015/648278.

7. Pampiglione S, Rivasi F, Angeli G, Boldorini R, Incensati RM, Pastormerlo M, Pavesi M, Ramponi A. Dirofilariasis due to Dirofilaria repens in Italy, an emergent zoonosis: report of 60 new cases. Histopathology 2001;38(4):344-54.

8. Boss JD, Sosne G, Tewari A. Ocular dirofilariasis: Ophthalmic implication of climate change on vector-borne parasites. Am J Ophthalmol Case Rep 2017;7:9-10. https:// doi.org/10.1016/j.ajoc.2017.04.004.

9. Ermakova L, Nagorny S, Pshenichnaya N, Ambalov Y, Boltachiev K. Clinical and laboratory features of human dirofilariasis in Russia. IDCases 2017;19;9:112-5. https:// doi.org/10.1016/j.idcr.2017.07.006. 